\title{
An Analysis of the Growth Trajectory of Monsanto
}

\author{
Rafaela Di Sabato Guerrante ${ }^{1}$, Adelaide Maria de Souza Antunes ${ }^{2}$, Nei Pereira Jr. ${ }^{3}$ \\ ${ }^{1}$ School of Chemistry, Federal University of Rio de Janeiro, UFRJ, Rio de Janeiro, Brazil; ${ }^{2}$ Department of Organic Chemistry, \\ School of Chemistry, Federal University of Rio de Janeiro, UFRJ/National Institution of Industrial Property, INPI, Rio de Janeiro, \\ Brazil; ${ }^{3}$ Department of Biochemical Engineering, School of Chemistry, Federal University of Rio de Janeiro, UFRJ, Rio de Janeiro, \\ Brazil. \\ Email: rafaelaguerrante@gmail.com, \{adelaide, nei\}@eq.ufrj.br
}

Received March 26 $6^{\text {th }}, 2010$; revised May $7^{\text {th }}, 2010$; accepted June $17^{\text {th }}, 2010$.

\begin{abstract}
The present article aims to present the trajectory of the Monsanto company in light of the main concepts and theories of Chandler, Penrose, Greiner and Fleck related to the growth dynamic of organizations. The analysis of the company's history from its foundation in 1901 to 2008 allows for the identification of recurring behaviors essential to its trajectory of continuous growth, and offer proof of its propensity to self-perpetuate. The company's organizational restructurings, decentralization of power, frequent diversification into related areas (foods, pharmaceuticals and genetically modified seeds), acquisition of, or forming of, joint ventures with companies already active in target markets, purchase of technological packages, contracting personnel specialized in areas of interest, long-term planning, use of the versatility and ambition of its leaders in the allocation of idle resources and services, amongst other activities, are hallmarks and characteristics of the journey of Monsanto.
\end{abstract}

Keywords: Monsanto, Trajectory, Growth, Firm, Restructuring, Diversification

\section{Introduction}

\subsection{The Monsanto Study Case Proposal}

The trajectory of the growth of the Monsanto Company presented in this article constitutes a case study representative of the major concepts and theories of Chandler [1-3], Penrose [4], Greiner [5] and Fleck [6-9] related to the growth dynamic of organizations.

\subsection{Literature Background - The Growth Dynamics of Organizations According to Chandler, Penrose, Greiner and Fleck}

As an initial step, it is necessary to provide a synthetic overview of the above-mentioned theories and their related concepts with the aim of identifying their similarities. Methodological reasons lead to the option to approach this task by author, rather than respecting the chronology of their publications.

\subsubsection{Chandler's View of the Strategies and Structures of Companies}

In Chandler's book entitled Strategy and Structure [1], the author analyzes the organizational restructuring of four companies: GE, DuPont, Jersey Standard and Sears, pioneers in the creation of decentralized organizational structures of the "multidivisional" type, in which a central office plans, coordinates and evaluates the activities of different divisions, and manages the distribution of needed resources to each of them. The pioneering role of these four companies in structuring themselves in this way owes much to that fact that they were the first to diversify. In these companies, diversification brought a larger and more complex number of tasks to be developed and administered, which, in turn came to demand a new "multidivisional" organizational structure, capable of managing the consequences of diversification.

In the same book, Chandler presents the thesis that differing organizational structures are the result of equally distinct types of business growth. He further adds that, in order to attain a determined level of growth, a company requires a strategy; this strategy in turn requiring a new (or redesigned) organizational structure capable of administrating the new resources and activities resulting from the growth. According to Chandler, a company is moved to alter its strategy when there are changes in the population (type, size, geographical area, etc.), fiscal changes or technological innovations. For the author, new strategies always precede new (or redesigned) 
organizational structures.

Another important aspect emphasized by this author in Strategy and Structure [1] is the reason why some companies, with their new strategies, lag in the development of the new (or redesigned) organizational structures essential to growth. According to Chandler, this delay is the responsibility of those company executives involved in long-term planning. For him, excessive involvement of entrepreneurs in the company's routine activities leaves them with little sensitivity for the identification of the needs and problems of the organization. Ill-trained executives, resistant to change and professionally insecure, are unlikely to be capable of identifying and understanding the long-term demands and opportunities of the company, especially those of an organizational character. This being the case, the personalities and experience of executives involved in strategic planning will have a profound influence on the way in which the company will restructure itself in order to grow.

In his work The Visible Hand [2], Chandler presents the structure of the new railroad network in the US, the fruit of many processes of technological innovation, which, in turn, came to require immediate changes in administrative organization. In this type of context, administrative coordination, to which Chandler applied the metaphor of the Visible Hand, became essential.

In the most recent work of Chandler [3], he compares the performance of the chemical and pharmaceutical industries and concludes that the different behaviors exhibited by them were the result of the existence of barriers to entry in their respective markets, of the strategies adopted, and of factors which limited the growth of companies. According to the author, the core companies, which he also refers to as first movers, are the first to move into a new market, but they are, however, incapable of creating an industry alone. They depend upon support companies (capital, equipment, raw materials, specialist, etc.), with whom they establish partnerships and alliances

\subsubsection{The Evolutionary and Revolutionary Phases of Company Growth According to Greiner}

Turning now to the work of Greiner [4], a number of similarities with Chandler's [1,3] ideas can be identified. The first of these is related to the fact that many companies are slow to restructure because of a lack of sensibility on the part of their executives, who, preoccupied with immediate growth and involved in routine company activities, are thus incapable of detecting, at the right moment, those structural problems which hinder the organization's long-term growth.

The second similarity lies in the presentation of the phases which a company passes through during its growth. These are evolutionary, interspersed with revolutionary periods. According to Greiner, the evolutionary periods present an administrative structure adopted in order to obtain growth. When this growth is attained, the revolutionary phase begins, in which the existing organizational structure is now no longer capable of meeting the needs of the company (as a result of its growth). There arises the need for organizational changes to occur so that the company can begin to grow again.

The third similarity is in that each growth phase requires different types of organizational and administrative structure, given that the strategies of the company are distinct in each phase.

The fourth similarity is related to the critique developed by Greiner in regard to a centralized organizational structure within companies which have diversified activities. He believes, as does Chandler [1,3], that the probability of failure is high in this context.

\subsubsection{The Penrosian Analysis of the Influence of Human Resources in Company Growth}

Penrose [4], in turn, understands the firm as being more than an administrative unit; it is also a set of productive resources whose disposition for diverse uses through time is determined by administrative decisions.

The theory of company growth, according to Penrose [4], seeks to examine the changing productive opportunities available to the company, with the aim of determining if there are limits or not to its growth, or restrictions on its rhythm. Penrose points out that her analysis is not focused merely on simple company growth, but on the effort of a group of people with defined objectives. According to her, there does not exist an optimum size for a company to be most profitable, and the increase in its size should be understood simply as a byproduct of its growth process.

In the same work, Penrose emphasizes the importance of analysis of the forces inherent in the nature of firms, which create opportunities for growth, while at the same time imposing limits on its rate of growth over a defined period of time. She adds, however, that this limiting of growth is temporary, and that, once any expansion plan is concluded, it tends to diminish, given that a new disequilibrium arises, bringing with it new stimulus for company growth. This Penrosian analysis, which amongst other aspects, defends the organizational restructuring of the company in the face of external changes, bears a strong resemblance to the idea of Chandler [1], mentioned in Subsection 1.2.1.

Other similarities between the approaches of Chandler [1] and Penrose [5] can be pointed out. The first is in connection with Penrose's view of the progressive decentralization of authority and responsibility to subordinates as constituting a necessary condition for continued company growth. 
The next similarity lies in the emphasis placed by both authors on the importance of administration, and more specifically, on the role of administrators in company growth. Penrose envisions the administrative structure of the company as a creation of the people who control it, or, more specifically, as the result of a psychological predisposition on the part of the individuals who assume risk in the expectation of gain. Penrose lists a number of aptitudes essential to managers of a company seeking to grow; amongst these are versatility, the capacity to aggregate resources and to make cuts when necessary, as well as the most relevant: ambition. Along the same path as Penrose, Chandler [1] believes that company administrators are often not capable of perceiving the need for changes in organizational structure or any imminent market opportunities, due to three factors: excessive involvement on the part of the "entrepreneurs" in routine company activities, deficient training and/or a profile of insecurity and resistance to change.

Penrose also asserts that the capabilities of the current administrative personnel may impose a limit to the growth of a company in any given period, since such capabilities cannot be contracted in the market. This being the case, if a firm expands more quickly than its personnel can improve the skills needed to deal with the expansion, the company's efficiency may be affected. According to Penrose, slow turnover of personnel within a company is an advantage in terms of its growth, as its employees accumulate experience over the time worked experience which allows them to identify new productive opportunities for the company. At the same time, slow turnover of personnel allows the company to avoid the effort needed to train new employees, which in many cases may result in a lower growth rate. Chandler [2] disputes these ideas of Penrose and maintains that one of the reasons which allow the administrators of a new company to contribute to its growth is exactly the fact that they are subject to replacement through the contracting and training of new employees.

\subsubsection{The "Motors of Perpetual Growth" According to Fleck}

In the analysis which Fleck [6] makes of the work of Chandler [2], the author emphasizes that in the traditional model of a company, which held sway until the appearance of the modern business enterprise (MBE), growth was rarely planned over the long term to take into consideration possible changes in offer, demand and/or technology. The view of this author is that company growth was the result of immediate responses to shortterm needs and opportunities. Fleck asserts that company owners, who, in the traditional model, also exercised the role of administrators, had their attention permanently fixed on routine undertakings, which impeded them from planning for continuous growth. This observation was also emphasized by Chandler [2], as discussed in the Subsection 1.2.1.

Fleck [7] proposes the idea that a company which is experiencing continuous growth is capable of undertaking organizational renovation, thus avoiding stagnation and developing its capacity to survive. A correlation can be made here with Chandler's [1,2] approach, in which organizational restructuring is deemed an essential factor for any company seeking to grow.

In her article "Traços Organizacionais, Autoperpetuação e Autodestruição da Empresa" Fleck [8] proposes that superior performance by a company results from the development of dynamic capabilities, which employ organizational processes to gain, exploit and reconfigure those resources identified by the author as VRIO (Valuable, Rare, not amenable to being Imitated, and capable of being exploited by Organizational capabilities). A similarity can be drawn here between Fleck's position and the considerations of Penrose [4], as mentioned in Subsection 1.2.3, by which non-utilized productive services constitute a challenge to innovation, a stimulus for expansion and source of competitive advantage within an entrepreneurial company.

In Fleck [9], the author presents her "Modelo de Requisitos para o Desenvolvimento da Propensão a Autoperpetuação Organizacional”, a model of organizational self-perpetuation which is composed of various small "motors of perpetual growth", these motors also being developed in another work of Fleck [8]. Fleck [9] asserts as well that the non-related diversification of a company can lead it to fragmentation, and often to failure. It is important to remember that both Chandler [1] and Penrose [4], whose concepts were strongly used in Fleck's [9] analysis, accept, in their approaches, that one of the forms of company growth lies in its diversification into related areas. Other factors, which, according to Fleck [9], may also contribute to the failure of a company, are lack of ambition and versatility on the part of its management - this is consonant with Penrose's [4] ideas - and the lack of an administrative or managerial hierarchy, an aspect raised by Chandler [1] as an essential prerequisite for continued company growth.

\section{Methods}

The goal of the article is to elucidate the concepts and theories - cited in Subsections 1.2.1, 1.2.2, 1.2.3 and 1.2.4 - by means of actual events in the history of Monsanto, mostly culled from the work of Forrestal [10], which relates the history of the first 75 years of the company. More recent events have been selected from institutional articles, books and other sources within the company itself [11-18]. Emphasis has been placed on the existing synergies amongst the various theories of the 
dynamic of organizational growth proposed by the authors in question.

The episodes from the trajectory of Monsanto presented below compose a case study representative of the referred theories and concepts.

\section{Discussion - The Analysis of Monsanto Trajectory Based on Dynamic Growth Theories}

\subsection{Diversifying to Grow}

In concordance with the ideas of Chandler [1], Penrose [4] and Fleck [9], according to which one of the forms of company growth is its diversification into related areas, Monsanto has always sought to diversify into these, taking advantage of its dominance in certain product distribution channels and of the expertise of its personnel, the latter an achievement attained over time, as Penrose asserts, or by means of the contracting of market specialists, an idea which is opposed by her. According to Penrose, one way in which to minimize the risks and uncertainties which inhibit a company's growth is to divide its activities into different markets, provided that this diversification is in related areas. Fleck [9] lends support to the Penrosian view in affirming that non-related diversification can lead to fragmentation. Chandler [1,2] also makes clear his position in favor of diversification as a growth strategy.

The views of Chandler, Penrose and Fleck are confirmed in the trajectory of Monsanto, marked as it is by entries into different markets, and also by its failure in sectors unrelated to its main area of activity.

Following the structuring methodology proposed for this article, the facts below aim to embed the conclusions described above within the processes of diversification experienced by the company. These are:

- the entry of the company into the food additive market, beginning to produce in 1904 and 1905, respectively, caffeine and vanillin;

- the diversification into the pharmaceutical sector and its precursors, marked by the beginning of the production of phenacetin, an analgesic compound, of phenolphthalein, used in laxatives, of glycerol phosphates - present in nervous system tonics -, in 1912; in 1915, of nitrochlorobenzene, a raw material utilized in the synthesis of drugs, and in 1917 , by the expiration of the patent held by Bayer in the US for acetylsalicylic acid, which allowed Monsanto to add another product to its already very diverse portfolio;

- diversification in 1967 , into the following sectors: semiconductor materials, surfaces for sports and recreation, engineered composites, protein foods and graphics systems;

- and finally, migration to non-related areas, such as children's toys for schools and playgrounds, soybased beverages, and valves and control systems for industrial processes, following acquisition of the US Fisher Governor Company.

- In many of the diversification initiatives undertaken by Monsanto, the company presented recurrent behaviors in its attempts to overcome its lack of internal capacities in those areas in which it desired to act or to strengthen its participation. These behaviors consisted of: the acquisition of, or formation of joint ventures with, companies already active in target markets; the absorption of technology by means of licensing of technology packages; and the incorporation of tacit knowledge by hiring of human resources specializing in areas of interest. With regard to the acquisition of companies, many examples from the company's history may be cited. Amongst these are:

- the purchase, in 1920, of $50 \%$ of R. Graesser, a chemical company, leader in the production of phenol in the UK market. At this time, Monsanto perceived the excess of phenol in the post-WW1 US market, the need to find an alternate market for it, and the convenience of integrating it into the production of phenolphthalein. This was Monsanto's first step into international markets.

- the acquisition, in 1929, of two US industrial plants belonging to Rubber Service Laboratories, specializing in the production of chemical additives used in rubber processing, which allowed Monsanto to commence production of polymerization accelerators and antioxidants, amongst other additives.

- the acquisition in 1955, of the US Lion Oil Company, with the aim of integrating its assets, strengthening its activity in the petroleum sector, since Lion's nitrogenated products - anhydrous ammonia, nitric acid and ammonium nitrate could be used as a raw material in the production of Monsanto's fertilizer. This integration forced the company to turn its attention to the agricultural sector, with the creation of an action plan for the company in this market.

- the acquisition, 1969, of the US Farmers Hybrid Companies, a small group specializing in the production of corn hybrids, this being the first sign of Monsanto's interest in entering the market for genetically - modified (GM) seeds. Many other acquisitions of seed companies- Jacob Hartz, Agracetus, Agroceres, Anglo - Dutch Unilever, Asgrow Seed, Braskalb, Calgene, Dekalb, Grupo 
Maeda, Holden's Foundation Seed, Limagrain Canada Seeds, Plant Breeding International Cambridge (PBIC), Selected International Seeds Operations of Cargill, Sementes Hatã, Seminis, Western Seed and Poloni Semences - would follow this, leading to the company's consolidation in this area.

- the purchase of G. D. Searle, in 1985, an American pharmaceutical company, holder of the patent for aspartame, which was to expire in 1992. This acquisition provided Monsanto with the capabilities which it needed to establish itself in the pharmaceutical market.

The history of Monsanto also offers many examples of joint-ventures entered into with companies already active in markets of interest. The first of these took place in 1949, with the advent of the Chemstrand Corporation, result of a partnership between the company and the American Viscose Corporation, responsible for the development of synthetic fibers. One of the motives for this undertaking was Monsanto lack of knowledge of the synthetic fiber market.

A second example of partnership formation occurred in 1951, with the association of Monsanto and a Japanese company, with the intention of marketing some of its chemical products and setting up a subsidiary of this company in São Paulo for the fabrication of plastics. This is how the company began its activities in Brazil.

In addition to the joint-ventures mentioned, Monsanto has established many alliances with seed and biotechnology companies, aiming to solidify its activities in the GM seed market. ArQule, Cargill International, Cereon Genomics, Ecogen, FT-Pesquisa e Sementes, GeneTrace, Incyte Pharmaceuticals, the Institute of Plant Genetics, Mendel Biotechnology, Millennium Pharmaceutical and Mycogen are only a few examples of the partner companies with which Monsanto has formed joint-ventures.

It can be stated, based on the ideas of Chandler [3], that Monsanto was a first mover, that is, one of the first to enter the GM seed market. According to Chandler, however, these companies are not always able to found an industry on their own. They depend on other companies to supply support (capital, equipment, raw materials, specialists, etc.), and with whom to set up partnerships and alliances. This has been exactly Monsanto's strategy: establishing joint-ventures with companies specializing in biotechnology (dedicated biotechnology firms - DBFs), which possessed the technical knowledge about the genetic modification of organisms, as well as of the genes involved, while also buying up various seed companies, owners of the raw material to be modified. In this light, the DBFs, as well as the seed companies may be considered as support, "complementary" or "focused" compa- nies, as delineated by Chandler.

In regard to the practice of licensing technology packages with the aim of absorbing technologies of which Monsanto had no previous experience or, in many cases, knowledge, it is worth citing some examples:

- the licensing, in 1953, of technology for the production of urethane foam from isocyanates - protected by the patents of the German Farbenfabriken Bayer A. G. company, which allowed Monsanto to take advantage of a propitious moment in the North-American market for these types of foam; and

- the consolidation of Monsanto's entry into the GM seed market, through the absorption of genetic seed modification technology made available as a result of the joint-ventures entered into by the company and the DBFs. This was the case with soy, Roundup Ready canola and cotton both resistant to the herbicide Roundup, also owned by Monsanto, and Bt corn, resistant to insect pests.

At several points in its history, aiming to overcome its lack of internal know-how in certain areas, Monsanto has opted to contract, in the market, executives with experience in those sectors where the company envisioned future activity. This occurred in the $40 \mathrm{~s}$, with the hiring of two executives from outside the company, and in 1960, with the hiring of an ex-employee of Shell, specialized in agricultural chemicals. The main effect of the latter was the creation of its Agricultural Chemicals Division, responsible for Monsanto's fertilizers, pesticides and herbicides.

Returning to the innumerable processes of diversification experienced by Monsanto, it is important to emphasize the more relevant consequences of these, all of which were undertaken with the goal of optimizing management of the new necessities generated by diversification:

- the company's domestic and international expansion, with the aim of distributing its products, conquering new markets and/or strengthening it position in sectors where it was already active;

- the decentralization of power; and

- the constant organizational restructuring.

With regard to the conquering of new markets and the consolidation of the company's participation in others, of relevance is the work of Fleck [8], who understands, as does Penrose [4], that non-utilized productive services constitute, for the entrepreneurial company, a challenge to innovation, a stimulus for expansion and a source of competitive advantage, which, at many moments in Monsanto's history, have spurred the company to domestic and/or international expansion. According to the con- 
tinuous growth motor model proposed by Fleck [8], a company experiencing continuous growth is capable of experiencing organizational renewal, and thus avoiding stagnation, while cultivating its tendency to self-perpetuate. This has been the path followed by Monsanto throughout its history.

\subsubsection{Monsanto's Domestic and International Expansion}

Presented below are a number of episodes from the history of the company which demonstrate the movement of Monsanto into new markets, both domestic and international, and the consolidation of its participation in sectors in which it was already present. This expansion of the company may be seen as a way of attempting to allocate idle productive services as result of its growth. Worthy of mention are:

- the definitive consolidation, in 1946, of the company's international activities, with exports to all of Europe, the Philippines and South America, representatives in East Asia and India, as well as subsidiaries in the UK, Canada and Australia. In that year, in the post-war environment, world demand was greater than Monsanto's ability to meet it, and its exports exceeded those of the previous two war periods;

- the investment in increased capacity for the production of the company's two main herbicides 2,4-D (dichlorophenoxyacetic acid), produced as part of the WWII (1939-1945) chemical and biological warfare program, and 2,4,5-T (trichlorophenoxyacetic acid), used in the Vietnam War (1954-1975) as one of the compounds of the defoliant known as Agent Orange -, resulting from the expansion, in 1950, of the market for pesticides and herbicides in the Eastern US;

- and, demonstrating Monsanto's systematic vision the dividing of its international operations, in 1976, into four sectors: Europe-Africa, Canada, Latin America and Asia-Pacific, which allowed the redefinition and restriction of the range of the company's products in conformity with the needs of each market.

\subsubsection{Decentralizing Power in a Diversified Firm}

Chandler [1,3,19], Penrose [4] and Greiner [5] have highlighted the relevance of decentralizing power in diversified companies, as presented in Subsections 1.2.1, 1.2.2 and 1.2.3.

Transposing these ideas to the history of Monsanto, it can be seen that when Edgar Monsanto Queeny - son of John F. Queeny, founder of the company - took over the presidency in 1928, the range of its products was too large to be administered by a centralized structure, such as that implemented by his father, and still functioning at that time. Faced with this situation, Edgar saw the need for a restructuring of the management model, which would open the way for a more efficient administration of the new resources and productive services resulting from the variety of products sold by the company. Thus Edgar Queeny opted for decentralization and for delegation of authority, putting an end to the previous model, in which decision making was centralized in John Queeny, always present in the company's headquarters.

Another example of the delegation of authority to the company's employees took place in 1972, when John W. Hanley, upon becoming president of Monsanto, decided that its administrative model needed alteration, as each of its divisions had a differing management structure, as well as a distinct corporate personality. Based on this, during his time as president, Hanley defined the responsibilities of more than 6000 employees in terms of planning and implementing the company's technological resources, as well as their roles in improving existing products and processes, and in developing and implementing new company activities.

\subsubsection{The Constant Monsanto's Organizational Restructuring}

It may be said that almost all the organizational restructuring initiatives undertaken in Monsanto's history since its foundation fall neatly within the concepts discussed by Chandler [1,19] and Greiner [5] in Subsections 1.2.1 and 1.2.2. A few of these initiatives will be presented below as being representative of this type of behavior, given that a full accounting would be too large, and would fall outside the scope of this article.

The first of these dates from 1939, the year in which, as a result of the expectation of future company growth and the diversification of its products, an organizational restructuring plan was drawn up for the next fifteen years in the life of Monsanto. This restructuring envisaged the division of the company into smaller and more easily managed segments.

In 1952, Monsanto underwent yet another structural reorganization process, resulting from the increase in the number of its employees - which had reached 20000 and also from the expectation of growth in the immediate years to come. Given this context, the company bought a large site on the outskirts of St. Louis - city in the state of Missouri, where the company was founded in 1901, and where, one year later, it built its first industrial plant -, to which all its employees moved in 1957. This new headquarters allowed for the integration of all employees, placing workers from different levels of the hierarchy in the same location.

The 1970s may be characterized as a period of reali- 
gnment in the company's areas of activity. At the beginning of the decade Monsanto was fragmented into nine divisions, as well as three administrative departments. One reason for the high degree of fragmentation of the company is related, according to Fleck [9], to the nonrelated diversification undertaken by Monsanto. Faced with this problem, the company president realized that Monsanto needed major reorganization if it wanted to continue growing in the succeeding years. The criterion used for this major reorganization in 1971 was to group together, in the most efficient way, Monsanto's most profitable divisions. The result was reorganization into four large international companies: Monsanto Polymers and Petrochemicals, Monsanto Industrial Chemicals, Monsanto Textiles and Monsanto Commercial Products, result of the merging of the Agricultural, Packaging and Electronic Products divisions, as well as Monsanto Enviro-Chem Systems - responsible for licensing the environmental cleanup technologies patented by Monsanto to other companies and industries - and the Fisher Controls Company, specialized in the production of valves and control systems for industrial processes.

If the acquisition of the G. D. Searle pharmaceutical company allowed Monsanto, on the one hand, to gain a foothold in the pharmaceutical market, on the other hand it also created a need for further organizational change in regard to its capacity to redistribute its internal research capabilities, not simply because of the new focus on medicines, but also because of the large overlap between the research already being done within Monsanto and the research undertaken by the recently acquired company. The restructured organizational model chosen by Monsanto divided its various research centers into autonomous, self-sustaining units, with the capacity to control their own destinies and the resources they required. Priority was given to biotechnology and some areas of chemistry which had shown them to be of strategic importance.

The acquisition of Searle can be cited as an example of Monsanto's continued growth, as outlined by Fleck [8], in that it provided the company with the resources and capacity needed to gain a foothold in the pharmaceutical market. However, the newly-acquired resources - researchers with know - how in the production of pharmaceuticals, research laboratories and the equipments used to produce drugs - and productive services - competencies in the production of drugs and the then-existing lines of research within Monsanto and Searle - which, until then, Monsanto had lacked, served to create pressure within the company for a remodeled organizational structure (Chandler [1,2]) with the capacity to manage them (Penrose [4]).
The final example of restructuring to be mentioned dates from 1995, the year in which the company's traditional structure of divisions and product lines was split up into fifteen "Strategic Business Units", which are smaller, more flexible, agile, dynamic and oriented to markets of interest and consumer needs. The SBUs are presented in Table 1, below.

With this remodeled structure, Monsanto believed that it would now be easier to benefit from economies of scale, as other large companies had done, while at the same time being able to enjoy the flexibility and creativity found in small firms.

\subsection{The Influence of Leaders' Personalities in Monsanto's Grow}

Continuing along the line based on some ideas of Chandler [1], and supported by Penrose [4], Greiner [5] and Fleck [6], in regard to the influence of the behavioral profile of managers during its growth, some reflections on the personalities of Monsanto's most important leaders are in order.

Both John F. Queeny, founder of the company, as well as his son, Edgar, who inherited his father's place, may be said to reveal profiles of ambition, long-term vision and versatility, evidenced in the positions taken and the decisions made in their periods as president of the company. The purchase of the land on the outskirts of St. Louis for expansion, anticipating the company's growth, the acquisition of the two industrial plants belonging to the Rubber Service Laboratories, based on a perception of growth in the rubber additives market, and the negotiation with Bayer for the rights to urethane foam production technology are only a few of Edgar's initiatives which give some insight into his personality.

Edgar Queeny's ambitious nature is clearly illustrated in many events described by Forrestal [10], which trace

Table 1. Harmonic content of the line voltage recorded during a measurements survey.

\begin{tabular}{|c|c|c|}
\hline $\begin{array}{l}\text { Strategic Busi- } \\
\text { ness Unit (SBU) }\end{array}$ & Main Products & $\begin{array}{ll}\text { Strategic } & \text { Business } \\
\text { Unit (SBU) } & \\
\end{array}$ \\
\hline Crop Protection & $\begin{array}{l}\text { Herbicides - } \\
\text { Roundup }\end{array}$ & Crop Protection \\
\hline Fibers & $\begin{array}{l}\text { Nylon and acrylic } \\
\text { fibers }\end{array}$ & Fibers \\
\hline $\begin{array}{l}\text { Growth Enter- } \\
\text { prises }\end{array}$ & $\begin{array}{l}\text { New business } \\
\text { opportunities }\end{array}$ & Growth Enterprises \\
\hline Kelco & Food ingredients & Kelco \\
\hline Ceregen & $\begin{array}{l}\text { Agricultural prod- } \\
\text { ucts (chemical and } \\
\text { biochemical) }\end{array}$ & Ceregen \\
\hline $\begin{array}{l}\text { NutraSweet Con- } \\
\text { sumer Products }\end{array}$ & $\begin{array}{l}\text { Consumer prod- } \\
\text { ucts - Sweeteners }\end{array}$ & $\begin{array}{c}\text { NutraSweet Consumer } \\
\text { Products }\end{array}$ \\
\hline $\begin{array}{l}\text { Nutra Sweet In- } \\
\text { gredients }\end{array}$ & $\begin{array}{l}\text { Food ingredients } \\
\text { (sweeteners) }\end{array}$ & $\begin{array}{c}\text { Nutra Sweet Ingredi- } \\
\text { ents }\end{array}$ \\
\hline
\end{tabular}

Source: Harvard Business School [20]. 
the strategies he used to ensure that the company became a leader in the markets where it was active. Edgar's ambitiousness was, in part, the source of the aggressive and proactive posture which Monsanto has exhibited throughout its history.

With regard to John Queeny, Forrestal [10] mentions the difficulties he faced in finding the financial resources needed to found Monsanto. Once the new company was stable, however, all of John Queeny's free time was devoted to finding new investors, seeking lines of credit with banks, attracting new customers and constructing a company image of integrity and quality, all of which could guarantee access to financial resources over the medium term.

The versatility and systematic vision of both John and Edgar Queeny allowed Monsanto to enter and leave various distinct markets over time, exploiting the everchanging market conditions and opportunities.

Turning to Monsanto's other leaders after Edgar Queeny, several events also demonstrate ambitious and visionary characters amongst them. In 1970s, when the company's leadership identified the need to explore other fields of scientific knowledge, such as plant cellular biology and the protein expression mechanism in animals and humans. This perception coincided, and not by accident, with the discovery of restriction enzymes - responsible for catalyzing the cleavage of DNA at specific sites - in 1970, which discovery led to genetic modification of living organisms. The 1990s, in turn, was marked by many demonstrations of long-term vision, and of the ambition of the company's presidents, when it came to Monsanto's entry into the biotechnology market. The development of GM seeds, with the goal, amongst others, of fighting global hunger, reducing malnutrition and protecting the environment from the degrading aspects inherent in the agricultural process is another example of the influence of the personalities of Monsanto's management on the company's growth.

It is important to make clear, as suggested by Chandler [1] and Penrose [4] that this ideal profile of the entrepreneur is merely one of the conditions favorable to company growth; by itself it is not a sufficient guarantee. Other conjunctural conditions - amongst which, in this case, are both world wars, global political and economic changes and the development of new technological paradigms - should be taken into account. Nonetheless, the conjunctural analysis would be too large, and would fall outside the scope of this article.

\section{Conclusions}

The analysis of Monsanto's history in light of the main ideas and theories of Chandler, Penrose, Greiner and
Fleck in relation to the growth dynamics of organizations allows for the understanding of its continued growth trajectory and its propensity to self-perpetuate. Along its course, Monsanto has always sought to diversify into related areas, taking advantage of its dominance in certain product distribution channels and of the expertise of its personnel, the latter an achievement attained over time or by means of the contracting of market specialists. All company's experiences in entering into sectors unrelated to its main area of activity have failured. In most of the diversification initiatives undertaken by Monsanto, the company presented recurrent behaviors in its attempts to overcome its lack of internal capacities in those areas in which it desired to act or to strengthen its participation. These behaviors consisted of: the acquisition of, or formation of joint ventures with, companies already active in target markets; the absorption of technology by means of licensing of technology packages; and the incorporation of tacit knowledge by hiring of human resources specializing in areas of interest. In order to optimize management of the new necessities generated by the conquering of new markets and the consolidation of the company's participation in others, Monsanto had to expand to international and national markets; to decentralize power inside the institution and, mainly, to constant restructure the organization. This way, the idle productive resources arisen from Monsanto's growth constituted, for the entrepreneurial company, a challenge to innovation, a stimulus for expansion and a source of competitive advantage, feeding its "motor of perpetual growth".

\section{REFERENCES}

[1] A. Chandler, "Strategy and Structure," MIT Press, Massachusetts, 1962.

[2] A. Chandler, "The Visible Hand," Harvard University Press, Harvard, 1977.

[3] A. Chandler, "Shaping the Industrial Century: The Remarkable Story of the Evolution of the Modern Chemical and Pharmaceutical Industries," Harvard Business School Press, Harvard, 2005.

[4] L. Greiner, "Evolution and Revolution as Organizations Grow," Harvard Business Review, Vol. 76, No. 3, 1998, pp. 55-67.

[5] E. Penrose, "The Theory of the Growth of the Firm," Oxford University Press, Oxford, 1980 (1st Ed. 1959).

[6] D. Fleck, "Growth in Chandler's the Visible Hand," Relatórios Coppead, Rio de Janeiro, 2001.

[7] D. Fleck, "Dois Motores de Crescimento Corporativo," Revista de Administração de Empresas, Vol. 43, No. 4, 2003, pp. 10-24.

[8] D. Fleck, "Traços Organizacionais, Autoperpetuação e Autodestruição da Empresa," Working Paper - Coppead, 2003.

[9] D. Fleck, "Archetypes of Organizational Success and Failure,” Relatórios Coppead, Rio de Janeiro, 2006. 
[10] D. J. Forrestal, "Faith, Hope and $\$ 5,000$. The Story of Monsanto: The Trials and Triumphs of the First 75 Years," Simons and Shuster, New York, 1977.

[11] R. Guerrante, "Transgênicos: uma Visão Estratégica," Interciência, Rafaela Di Sabato Editora, 1977.

[12] C. Leonard, "Monsanto Announces Two Partnerships to Develop Biotech Crops," Associated Press, New York, 2007. http://nl. newsbank.com

[13] MONSANTO, 2008. http://www. monsanto.com

[14] "MONSANTO Company Acquires Agroeste Sementes, a Brazilian Corn Seed Company," Monsanto News Releases, 2007. http://monsanto.mediaroom.com/index.php? $\mathrm{s}=43$ \&item $=525$

[15] "MONSANTO's March into Biotechnology - B," Harvard Business School, Case No. 9-692-066, 1991.
[16] "MONSANTO's March into Biotechnology - A," Harvard Business School, Case No. 9-690-009, 1993.

[17] M. Watkins, "Robert Shapiro and Monsanto," Harvard Business School, Case No. 9-801-426, 2003.

[18] "World's Top Ten Seed Companies," ETC Group Publications, Ottawa, 2007. http://www.etcgroup.org/en/materials/publications.html?pub_id $=615$

[19] A. Chandler, "The Evolution of Corporate Capabilities Strategy and Structure within the World's Largest Chemical Firms: The 20th Century in Perspective," In: A. Arora, R. Landau and N. Rosenberg, Eds., Chemicals and Long-Term Economic Growth, Wiley, Hoboken, 1998.

[20] "MONSANTO Company - The Coming Age of BioTechnology," Harvard Business School, Case No. 9596-034, 1996. 